\title{
Influence of Biofertilizer and Auxin on Growth and Rooting of Pomegranate (Punica granatum L.) Cuttings
}

\author{
Abdul Hakim*, S. Jaganath, M.K. Honnabyraiah, S. Mohan Kumar, \\ S. Anil Kumar and K.J. Dayamani \\ Department of Fruit Science, College of Horticulture, UHS Campus, GKVK Post, \\ Bengaluru, Karnataka-560 065, India \\ *Corresponding author
}

\section{A B S T R A C T}

Studies on the influence of bio-fertilizers and auxin on growth and rooting of pomegranate (Punica granatum L.) cuttings cvs. Bhagwa and Ruby was conducted at the department of

\section{Keywords}

Pomegranate

(Punica granatum

L.), Growth,

Rooting

\section{Article Info}

Accepted:

10 January 2018

Available Online:

10 February 2018 fruit science, College of Horticulture, B during 2015-2016. The results revealed that the early sprouting of cuttings (8.60 and 7.80 days), number of cutting sprouted (18.33 and 17.67), length of longest shoot (39.73 and $41.53 \mathrm{~cm})$, number of leaves (41.67 and 44.60), fresh weight of shoots $(10.80$ and $12.60 \mathrm{~g})$, dry weight of shoots $(5.80$ and $6.60 \mathrm{~g})$, number of primary roots (11.67 and 10.73), number of secondary roots (58.60 and 54.67), root length $(27.60$ and $25.80 \mathrm{~cm})$, fresh weight of roots $(2.56$ and $2.75 \mathrm{~g})$ dry weight of roots ( 1.62 and $1.85 \mathrm{~g}$ ) were recorded significantly maximum value in both the cvs. Bhagwa and Ruby, respectively with application of IBA $1500 \mathrm{ppm}+$ NAA $1500 \mathrm{ppm}+$ Biomix in $\left(\mathrm{T}_{6}\right)$. While, number of sprout (3.07), diameter of sprouts $(3.16 \mathrm{~mm})$, recorded maximum with treatment $\left(\mathrm{T}_{6}\right)$, in cv. Ruby and maximum number of sprout (2.80), diameter of sprouts $(3.07 \mathrm{~mm})$ were recorded significantly higher in $\mathrm{cv}$. Bhagwa with treatment IBA $1500 \mathrm{ppm}$ + NAA $1500 \mathrm{ppm}$ + PSB + PGPR, $\left(\mathrm{T}_{10}\right)$. Whereas, all the above mentioned parameters were significantly reduced in control.

\section{Introduction}

The pomegranate (Punica granatum L.) belongs to the family punicaceae which is one of the favourite table fruits of the tropical and subtropical regions. Pomegranate is growing best in semi-arid climate where cool winter and hot summer prevails. The rooting capability of cuttings varies from cultivar, location, season and age of the branch. Besides, growth regulators and bio-fertilizers also play an important role in rooting and growth of pomegranate cutting. Therefore in order to improve rooting ability and success per cent, techniques have been improved with the use of synthetic root promoting growth regulator and biofertilizers (Damar et al., 2014). The application of Indole Butyric Acid (IBA) and Naphthalene Acetic Acid (NAA) induce rooting in stem cuttings and in air layers due to their ability to activate cambium regeneration, cell division and cell multiplication (Rymbai and Reddy, 2010). The combined effect of biofertilizers and 
growth regulator have showed better root and shoot parameters which could be attributed to increased levels of growth promoting substance available due to synergistic effect of both biofertilizer and growth regulators in various ways (Damar et al., 2014).

\section{Materials and Methods}

The present investigation was carried out during 2015-16, in the department of fruit science, College of Horticulture, UHS Campus, GKVK, Bengaluru -560065, Karnataka, India. The experiments were laid out in RBD (Randomized Block Design), and the stem cuttings of pomegranate cultivars Bhagwa and Ruby were taken into study. The experiments consist of eleven treatment combination auxin and biofertilizers were taken into study viz. $T_{1}$ - IBA 1000 ppm + NAA 1000 ppm, T T $_{2}$ IBA 1500 ppm + NAA 1500 ppm, $\mathrm{T}_{3}$ - IBA $1000 \mathrm{ppm}$ + NAA 1000 ppm + Biomix, $\mathrm{T}_{4}-$ IBA $1000 \mathrm{ppm}+\mathrm{NAA}$ $1000 \mathrm{ppm}+\mathrm{PSB}, \mathrm{T}_{5}-\mathrm{IBA} 1000 \mathrm{ppm}+\mathrm{NAA}$ $1000 \mathrm{ppm}+\mathrm{PGPR}, \mathrm{T}_{6}-$ IBA $1500 \mathrm{ppm}+$

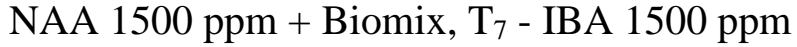
+ NAA $1500 \mathrm{ppm}$ + PSB, T - IBA 1500 ppm + NAA $1500 \mathrm{ppm}+\mathrm{PGPR}, \mathrm{T}_{9}-\mathrm{IBA} 1000$ $\mathrm{ppm}+\mathrm{NAA} 1000 \mathrm{ppm}+\mathrm{PSB}+\mathrm{PGPR}, \mathrm{T}_{10}-$ IBA $1500 \mathrm{ppm}$ + NAA $1500 \mathrm{ppm}+\mathrm{PSB}+$ PGPR and $\mathrm{T}_{11}$ - Control. Twenty five cuttings were used for each treatment which was replicated thrice. The stem cuttings were treated to different concentration of auxin solution for 6 hours and planted in a media of sand, soil and fym $(1: 1: 1)$ equal proportion along with the biofertilizers (PGPR, PSB and Biomix) $10 \mathrm{~g} /$ pot. The cuttings were kept under shade net.

\section{Results and Discussion}

\section{Growth parameters}

All growth parameters in both the cvs. Bhagwa and Ruby significantly influenced by biofertilizers and auxin are present in (Table 1 and 2). The data indicated that the cuttings treated with IBA 1500 ppm + NAA 1500 ppm + Biomix $\left(\mathrm{T}_{6}\right)$ showed early sprouting of cuttings (8.60 and 7.80 days), number of cutting sprouted (18.33 and 17.67), length of longest shoot $(39.73$ and $41.53 \mathrm{~cm})$, number of leaves (41.67 and 44.60), fresh weight of shoots (10.80 and $12.60 \mathrm{~g})$, dry weight of shoots (5.80 and $6.60 \mathrm{~g}$ ), were recorded significantly higher values in cvs. Bhagwa and Ruby, respectively, which was on par with the treatment combination IBA $1500 \mathrm{ppm}+\mathrm{NAA}$ $1500 \mathrm{ppm}+\mathrm{PSB}+\mathrm{PGPR}\left(\mathrm{T}_{10}\right)$, while, number of sprout (3.07), diameter of sprouts $(3.16 \mathrm{~mm})$, recorded maximum with treatment $\left(\mathrm{T}_{6}\right)$, in cv. Ruby and maximum number of sprout (2.80), diameter of sprouts $(3.07 \mathrm{~mm})$ were recorded significantly higher in cv. Bhagwa in treatment $\left(\mathrm{T}_{10}\right)$. Whereas, the control had the least effect on the development of the cuttings in all the parameters in both cultivars.

The early sprouting of cuttings may be due to increased level of auxins which resulted in earlier completion of physiological processes in rooting and sprouting of cuttings. These results are in conformity with Damar et al., (2014). Similarly, the cuttings treated with IBA 5000 ppm concentration took minimum duration in sprouting (8.75 days) whereas longest (9.73 days) in control (Srivastava, et al., 2008). The increase number of cutting sprouted may be associated with cell division stimulated by the auxin at the sprout union. Bhatt and Tomar (2010) in a similar study obtained the maximum number of sprouted cuttings with growth regulators IBA 500 ppm. Similarly, Singh et al., (2009) reported that the cuttings treated with IBA 100 ppm (slow dip) and $2000 \mathrm{ppm}$ (quick dip) resulted in maximum (90.96\%) sprouting compared to (47.32 \%) sprouting in control. According to result, the IBA treatment increased the sprouting percentage compared to the control. 
The increase number of sprouts per cutting may be attributed to increased cell division and elongation at higher concentrations of IBA as reported by Singh and Pande (1986) found positive effect in number of shoots per cutting and number of leaves per shoots, with 1500 ppm IBA in hard wood stem cuttings of sweet lime (Citrus limettiodes). Similarly, Barde et al., (2010) reported that IBA at 2000 ppm gave maximum number of shoot per cutting (2.80), with combination of PSB and 2000 ppm IBA. Alikhani et al., (2011) also reported that among various treatments, stem cuttings of pomegranate with more than three buds treated with NAA 4000 ppm concentration gave maximum shoots per cutting (2.73).

The increase thickness in the sprout maybe contributed to the auxin and biofertilizers as Patil et al., (2000) recorded maximum diameter of thickest sprout per rooted cuttings treated with 100 ppm IBA. Similarly, Yasser (2015) reported that, IBA 1500 + NAA 1500 ppm with Biomix + Glomus mosseae has resulted in greater diameter. Purohit and Shekharappa (1985) concluded that pomegranate basal cuttings treated with 5000 ppm IBA gave the longest sprout per cutting. Similarly, Singh (2014) reported that, the stem cuttings of Punica granatum L. treated with different concentration of IBA. Among all the treatments, average length of sprout (20.53 $\mathrm{cm}$ ), was noticed in $5 \mathrm{~g} . \mathrm{L}^{-1}$ concentration of IBA. Barde et al., (2010) also reported that IBA at $2000 \mathrm{ppm}$ gave maximum length of shoot $(22.94 \mathrm{~cm})$, number of shoot per cutting (2.80), with combination of PSB and 2000 ppm IBA.

The increase in number of leaves may be attributed to increased cell division and elongation at higher IBA concentrations and its possible reason for increase and activation of shoot growth which probably increased the number of nodes that lead to development of more number of leaves. Similarly, Damar et al., (2014) reported that, among different treatments of bio-fertilizers and growth regulators the total number of leaves per shoot and per cutting was significantly higher in IBA 2000 ppm. Singh and Pande (1986) found positive effect in number leaves per shoots, with $1500 \mathrm{ppm}$ IBA in hard wood stem cuttings of sweet lime (Citrus limettiodes). The probable reason for increase in fresh and dry weight of shoots and roots may be the better utilization of carbohydrates, nitrogen and other nutrients which has been aided by growth regulators. Yasser, (2015) reported that, IBA 1500 + NAA 1500 ppm with Biomix + Glomus mosseae has resulted in higher fresh weight of sprout $(9.00 \mathrm{~g})$, highest dry weight of shoot $(4.93 \mathrm{~g})$, higher fresh weight of root $(2.90 \mathrm{~g})$ and highest dry weight of root (1.86 g).

\section{Root parameters}

All the root parameters in both the cvs. Bhagwa and Ruby significantly influenced by biofertilizers and auxin are present in Table 3 and 4 . The results revealed that significantly maximum number of primary roots (11.67 and 10.73 and), secondary roots (58.60 and 54.67), root length $(27.60$ and $25.80 \mathrm{~cm})$, diameter of longest root $(1.83$ and $1.75 \mathrm{~mm})$, fresh weight of roots $(2.56$ and $2.75 \mathrm{~g})$ dry weight of roots (1.62 and 1.85 and $\mathrm{g}$ ) were recorded in cvs. Bhagwa and Ruby, respectively with application of IBA $1500 \mathrm{ppm}+$ NAA 1500 ppm + Biomix in $\left(\mathrm{T}_{6}\right)$. Whereas, all the above mentioned parameters were significantly reduced in control.

The increase in primary and secondary roots may be due to more uptake and utilization of phosphorus, nitrogen and other nutrients by the cuttings under this treatment. Thakur et al., (2014) reported that the maximum number of primary roots $(7.85)$ in olive was recorded in cuttings treated with IBA 4000 ppm. 
Table.1 Influence of bio-fertilizer and auxin on days taken for sprout initiation, number of cutting sprouted, number of sprouts per cutting and diameter of sprouts in pomegranate cultivars

\begin{tabular}{|c|c|c|c|c|c|c|c|c|}
\hline \multirow[t]{2}{*}{ Treatments } & \multicolumn{2}{|c|}{$\begin{array}{l}\text { Days taken for } \\
\text { sprout initiation }\end{array}$} & \multicolumn{2}{|c|}{$\begin{array}{l}\text { Number of } \\
\text { cutting sprouted }\end{array}$} & \multicolumn{2}{|c|}{$\begin{array}{c}\text { Number of sprouts } \\
\text { per cutting }\end{array}$} & \multicolumn{2}{|c|}{$\begin{array}{l}\text { Diameter of } \\
\text { sprouts }\end{array}$} \\
\hline & Bhagwa & Ruby & Bhagwa & Ruby & Bhagwa & Ruby & Bhagwa & Ruby \\
\hline$T_{1}$ & 12.40 & 11.53 & 14.00 & 13.33 & 1.67 & 1.73 & 2.11 & 2.30 \\
\hline$\overline{T_{2}}$ & 12.07 & 10.93 & 14.67 & 14.00 & 1.73 & 1.87 & 2.29 & 2.42 \\
\hline $\mathbf{T}_{3}$ & 11.27 & 9.87 & 16.00 & 15.33 & 2.13 & 2.20 & 2.59 & 2.73 \\
\hline$T_{4}$ & 11.60 & 10.60 & 15.33 & 14.67 & 1.87 & 2.00 & 2.39 & 2.53 \\
\hline$T_{5}$ & 11.40 & 9.33 & 15.67 & 15.00 & 2.00 & 2.07 & 2.49 & 2.63 \\
\hline $\mathrm{T}_{6}$ & 8.60 & 7.80 & 18.33 & 17.67 & 2.60 & 3.07 & 2.98 & 3.16 \\
\hline$\overline{T_{7}}$ & 10.00 & 8.67 & 17.00 & 16.67 & 2.47 & 2.53 & 2.79 & 2.98 \\
\hline $\mathrm{T}_{8}$ & 10.40 & 8.53 & 17.33 & 16.33 & 2.33 & 2.60 & 2.89 & 2.90 \\
\hline $\mathrm{T}_{9}$ & 10.60 & 8.93 & 16.33 & 15.67 & 2.27 & 2.33 & 2.69 & 2.81 \\
\hline $\mathbf{T}_{10}$ & 9.33 & 8.27 & 17.67 & 17.00 & 2.80 & 2.87 & 3.07 & 3.06 \\
\hline $\mathbf{T}_{11}$ & 13.07 & 12.07 & 13.33 & 12.67 & 1.53 & 1.60 & 1.94 & 2.12 \\
\hline SE.m \pm & 0.38 & 0.31 & 0.59 & 0.44 & 0.07 & 0.06 & 0.06 & 0.10 \\
\hline CD at $5 \%$ & 1.12 & 0.91 & 1.74 & 1.30 & 0.21 & 0.17 & 0.18 & 0.29 \\
\hline CV & 15.99 & 15.49 & 12.40 & 14.98 & 9.68 & 10.13 & 14.11 & 9.34 \\
\hline
\end{tabular}

Table.2 Influence of bio-fertilizer and auxin on length of longest shoot, number of leaves per cutting, fresh and dry weight of shoots in pomegranate cultivars

\begin{tabular}{|c|c|c|c|c|c|c|c|c|}
\hline \multirow[t]{2}{*}{ Treatments } & \multicolumn{2}{|c|}{$\begin{array}{l}\text { Length of longest } \\
\text { shoot }(\mathrm{cm})\end{array}$} & \multicolumn{2}{|c|}{$\begin{array}{c}\text { Number of leaves } \\
\text { per cutting }\end{array}$} & \multicolumn{2}{|c|}{$\begin{array}{l}\text { Fresh weight of } \\
\text { shoots }(\mathrm{g})\end{array}$} & \multicolumn{2}{|c|}{$\begin{array}{l}\text { Dry weight of } \\
\text { shoots (g) }\end{array}$} \\
\hline & Bhagwa & Ruby & Bhagwa & Ruby & Bhagwa & Ruby & Bhagwa & Ruby \\
\hline$T_{1}$ & 24.60 & 26.80 & 22.60 & 24.60 & 5.33 & 6.80 & 2.67 & 2.60 \\
\hline$T_{2}$ & 25.80 & 27.60 & 24.73 & 25.40 & 5.73 & 7.60 & 2.80 & 2.80 \\
\hline$T_{3}$ & 29.53 & 31.40 & 30.67 & 31.80 & 7.47 & 9.47 & 3.87 & 3.80 \\
\hline $\mathbf{T}_{4}$ & 26.67 & 28.53 & 26.40 & 27.60 & 6.20 & 8.40 & 3.40 & 3.33 \\
\hline$T_{5}$ & 27.60 & 29.47 & 28.73 & 29.73 & 6.80 & 8.80 & 3.67 & 3.67 \\
\hline$T_{6}$ & 37.67 & 39.47 & 41.67 & 44.60 & 10.80 & 12.60 & 5.80 & 6.60 \\
\hline$T_{7}$ & 33.60 & 37.60 & 34.60 & 38.60 & 8.40 & 10.80 & 4.60 & 4.80 \\
\hline$T_{8}$ & 35.80 & 35.40 & 36.53 & 35.53 & 8.80 & 10.40 & 4.80 & 4.60 \\
\hline$T_{9}$ & 31.40 & 33.33 & 32.40 & 33.67 & 7.87 & 9.73 & 4.27 & 4.20 \\
\hline$T_{10}$ & 39.73 & 41.53 & 38.60 & 41.47 & 9.80 & 11.73 & 5.20 & 5.80 \\
\hline$T_{11}$ & 23.40 & 25.60 & 20.40 & 23.40 & 4.80 & 5.67 & 2.33 & 2.47 \\
\hline SE.m \pm & 0.94 & 0.80 & 0.63 & 0.88 & 0.55 & 0.24 & 0.26 & 0.21 \\
\hline CD at $5 \%$ & 2.76 & 2.36 & 1.85 & 2.60 & 1.64 & 0.71 & 0.76 & 0.63 \\
\hline CV & 12.41 & 11.27 & 13.53 & 12.73 & 12.88 & 10.78 & 11.37 & 9.14 \\
\hline
\end{tabular}


Table.3 Influence of bio-fertilizer and auxin on number of primary, secondary roots per rooted cuttings, length of longest root in pomegranate cultivars

\begin{tabular}{|c|c|c|c|c|c|c|}
\hline \multirow[t]{2}{*}{ Treatments } & \multicolumn{2}{|c|}{$\begin{array}{c}\text { Number of primary } \\
\text { roots }\end{array}$} & \multicolumn{2}{|c|}{$\begin{array}{c}\text { Number of secondary } \\
\text { roots }\end{array}$} & \multicolumn{2}{|c|}{$\begin{array}{l}\text { Length of longest root } \\
(\mathrm{cm})\end{array}$} \\
\hline & Bhagwa & Ruby & Bhagwa & Ruby & Bhagwa & Ruby \\
\hline$T_{1}$ & 7.27 & 6.20 & 34.67 & 28.60 & 15.73 & 13.73 \\
\hline $\mathbf{T}_{2}$ & 7.67 & 6.60 & 36.60 & 30.67 & 16.60 & 14.67 \\
\hline$T_{3}$ & 9.20 & 8.20 & 42.73 & 38.73 & 19.73 & 17.67 \\
\hline$T_{4}$ & 8.40 & 7.40 & 38.60 & 34.60 & 17.67 & 15.80 \\
\hline$T_{5}$ & 8.80 & 7.80 & 40.67 & 36.67 & 18.80 & 16.73 \\
\hline$T_{6}$ & 11.67 & 10.73 & 58.60 & 54.67 & 27.60 & 25.80 \\
\hline $\mathbf{T}_{7}$ & 10.80 & 8.80 & 52.67 & 44.67 & 22.60 & 20.53 \\
\hline$T_{8}$ & 10.33 & 9.40 & 50.60 & 48.73 & 23.67 & 21.80 \\
\hline$T_{9}$ & 9.60 & 8.40 & 46.80 & 40.60 & 21.67 & 18.73 \\
\hline$T_{10}$ & 11.20 & 9.80 & 55.67 & 52.60 & 25.60 & 23.60 \\
\hline$T_{11}$ & 6.53 & 5.60 & 29.67 & 25.53 & 14.40 & 12.60 \\
\hline SE.m \pm & 0.33 & 0.28 & 1.10 & 0.96 & 0.62 & 0.58 \\
\hline CD at $5 \%$ & 0.97 & 0.84 & 3.23 & 2.83 & 1.84 & 1.70 \\
\hline $\mathrm{CV}$ & 10.18 & 12.09 & 14.29 & 10.78 & 8.96 & 14.15 \\
\hline
\end{tabular}

Table.4 Influence of bio-fertilizer and auxin on diameter of longest root, fresh and dry weight roots in pomegranate cultivars

\begin{tabular}{|l|c|c|c|c|c|c|}
\hline \multirow{2}{*}{ Treatments } & \multicolumn{2}{|c|}{$\begin{array}{c}\text { Diameter of longest } \\
\text { root }\end{array}$} & \multicolumn{2}{|c|}{ fresh weight of roots } & \multicolumn{2}{|c|}{ Dry weight of roots } \\
\cline { 2 - 7 } & Bhagwa & Ruby & Bhagwa & Ruby & Bhagwa & Ruby \\
\hline $\mathrm{T}_{\mathbf{1}}$ & 1.38 & 1.32 & 1.45 & 1.55 & 0.65 & 0.85 \\
\hline $\mathrm{T}_{\mathbf{2}}$ & 1.43 & 1.38 & 1.54 & 1.65 & 0.75 & 0.95 \\
\hline $\mathrm{T}_{\mathbf{3}}$ & 1.59 & 1.52 & 1.85 & 1.95 & 0.99 & 1.25 \\
\hline $\mathrm{T}_{4}$ & 1.48 & 1.42 & 1.64 & 1.76 & 0.85 & 1.00 \\
\hline $\mathrm{T}_{\mathbf{5}}$ & 1.53 & 1.47 & 1.75 & 1.85 & 0.93 & 1.14 \\
\hline $\mathrm{T}_{\mathbf{6}}$ & 1.83 & 1.75 & 2.56 & 2.75 & 1.62 & 1.85 \\
\hline $\mathrm{T}_{\mathbf{7}}$ & 1.74 & 1.61 & 2.13 & 2.35 & 1.25 & 1.55 \\
\hline $\mathrm{T}_{\mathbf{8}}$ & 1.70 & 1.66 & 2.25 & 2.25 & 1.35 & 1.45 \\
\hline $\mathrm{T}_{\mathbf{9}}$ & 1.65 & 1.56 & 1.95 & 2.15 & 1.15 & 1.35 \\
\hline $\mathrm{T}_{\mathbf{1 0}}$ & 1.79 & 1.71 & 2.36 & 2.54 & 1.45 & 1.75 \\
\hline $\mathrm{T}_{\mathbf{1 1}}$ & 1.33 & 1.25 & 1.35 & 1.45 & 0.60 & 0.80 \\
\hline $\mathrm{SE}_{\mathbf{m} \mathbf{m} \pm}$ & 0.05 & 0.05 & 0.05 & 0.05 & 0.03 & 0.04 \\
\hline CD at 5\% & 0.15 & 0.16 & 0.16 & 0.15 & 0.09 & 0.12 \\
\hline CV & 9.86 & 12.25 & 12.81 & 10.43 & 11.05 & 12.70 \\
\hline
\end{tabular}


Srivastava et al., (2008) observed that, the maximum number of primary, secondary and average root number $(7.68,49.0$ and 75.0, respectively) were recorded at $5000 \mathrm{ppm}$ IBA concentration in kiwifruit. Yasser, (2015) also reported that, IBA 1500 +NAA 1500 ppm with Biomix + Glomus mosseae has resulted highest rooting in pomegranate stem cutting. Regeneration of pomegranate stem cuttings taken from 12 year old pomegranate tree (cv. Dholka) when treated with five different strengths of IBA and IAA each showed that 5000 ppm IBA treatment gave the longest root $(5.15 \mathrm{~cm})$ in hardwood cuttings (Panda and Das, 1990).

Patil et al., (2004) observed that the maximum root length $(8.25 \mathrm{~cm})$, highest number of roots emerged (42.25) noticed in the treatment involving the inoculation with P-solubilizing bacteria (PSB) alone followed by again PSB along with Azospirillum in pomegranate.

The increase in root diameter may be due to early initiation of roots in higher concentrations of IBA which has been favorably supported by moderate environment conditions created by mist and more utilization of the food materials due to early formation of the treated cuttings. Pirlak (2000) reported that Root diameter increased by hormone application (6000 ppm IBA). The probable reason for increase in fresh and dry weight of roots may be the better utilization of carbohydrates, nitrogen and other nutrients which has been aided by growth regulators. Yasser, (2015) reported that, IBA 1500 +NAA 1500 ppm with Biomix + Glomus mosseae has resulted in higher fresh weight of sprout $(9.00 \mathrm{~g})$, highest dry weight of shoot $(4.93 \mathrm{~g})$, higher fresh weight of root $(2.90 \mathrm{~g})$ and highest dry weight of root (1.86 g). Galavi et al., (2013) found that grape fresh and dry root weight significantly increased by effect IBA 4000 ppm
The study revealed that growth of different shoot and root parameters were found to be significantly influenced by bio-fertilizers and auxin. The effect of different concentration of auxin in combination with bio-fertilizers showed that the treatment IBA $1500 \mathrm{ppm}+$ NAA $1500 \mathrm{ppm}+$ Biomix $\left(\mathrm{T}_{6}\right)$ and treatment IBA $1500 \mathrm{ppm}$ + NAA $1500 \mathrm{ppm}+\mathrm{PSB}$ + PGPR $\left(T_{10}\right)$ had significantly higher values on different shoot and root parameters in both cultivars. Hence, it could be concluded that the combined effect of bio-fertilizer and auxin showed better result with respect to root and shoot parameters in both cultivars.

\section{References}

Alikhani, L., K. Ansari, M., Jamnezhad and Tabatabaie, Z., 2011. The effect of different mediums and cuttings on growth and rooting of pomegranate cuttings. Iranian J. Pl. Physi., 1(3): 199-203.

Barde, P., Tiwari, R., Kanpure, R. N., Baghel, B. S. And Kumawat, B. R., 2010. Effect of biofertilizers and growth regulators on rooting and growth of pomegranate cuttings. Ann. Soil. Res., 12(1): 46-47.

Bhatt, B. B. and Tomar, Y. K., 2010, Effects of IBA on rooting performance of Citrus auriantifolia Swingle (Kagzilime) in different growing conditions. India J., Garhwal Univ. Dept. Hort., 8(7): $8-11$.

Damar, D., Barholia, A. K., Lekhi, R. and Haldar, A., 2014, Effect of growth regulators and bio-fertilizers on survival of pomegranate (Punica granatum L.) stem cuttings. Ind. College of Agric., R.V.S.K.V.V., 14 (1): 347-350.

Galavi, M., Karimian, M. A. and Mousavi, S. R., 2013, Effects of different auxin (IBA) concentrations and planting-beds on rooting grape cuttings (Vitis vinifera). Iran Univ. of Zabol, Dept of Agri., 3(4): 517-523. 
Panda, J. M., and Das, R. C., 1990, Regeneration of pomegranate stem cuttings treated with IAA and IBA under intermittent mist. Orissa, J. Hort., 18: 32-37.

Patil, A. B., Nirmalnath, J. P. and Patil, S. R., 2004, Studies on promotion of rooting in air layers of pomegranate as influenced by microbial inoculants. Karnataka J. Agric. Sci., 17(4): 861863.

Patil, V. N., Chauhan, P. S., Panchabhai, D. M., Shivankar, R. S. and Tannirawar, A. V., 2000, Effects of growth regulators on rooting of hardwood cuttings of some commercial grape varieties. $J$. Soils and Crops, 10: 295-297.

Pirlak, L., 2000, Effect of different cutting times and IBA doses on the rooting rate of hard wood cuttings of cornelian cherry (Cornus mas L.). Atatark Univ. Dept. of Hort., 10 (1): 122-134.

Purohit, A. G. and Shekharappa, K. E., 1985, Effect of type of cutting and IBA on rooting of hardwood cuttings of pomegranate. Ind. J. of Hort., 42: 30-36.

Rymbai, H., Reddy, G., 2010, Effect of IBA, time of layering and rooting media on air-layers and plantlets survival under different growing nursery conditions in guava. Ind. J. Hort., 67: 99-104.

Singh, A. R. and Pande, N. C., 1986, Studies on the regeneration of sweet lime by stem cutting with the aid of IBA and NAA. Haryana J. Hort. Sci., 15: 25-28.

Singh, B., Singh, S. and Singh, G., 2009, Influence of planting time and IBA on rooting and growth of pomegranate (Punica granatum L.) cv 'Ganesh' cuttings. ISHS. Acta. Hort., 890, Int. sym. of pomegranate.

Singh, K. K., 2014, Effect of IBA concentrations on the rooting of pomegranate (Punica granatum L.) cv. Ganesh hardwood cuttings under mist house condition. Pl. Arch. 14(2) 11111114.

Srivastava, K. K., Hamid, S., Das, B. and Bhatt, K.M., 2008, Effect of Indole butyric acid and variety on rooting of leafless cutting of Kiwifruit under zeroenergy-humidity-chamber. ENVIS Bul. 14(1): 1-4.

Thakur, M., Sharma, D. D. and Singh, K., 2014, Studies on the effect of girdling, etiolation and auxins on rooting of olive (Olea europaea L.) cuttings. Himachal Pradesh, Int. J. Farm Sci., 4(2): 39-46.

Yasser, A. S., 2015, Effect of growth regulators and bio-fertilizers on rooting and growth of pomegranate (Punica granatum L.) stem cuttings. M.Sc.(Hort) Thesis, Univ. Hort. Sci., Bagalkot.

\section{How to cite this article:}

Abdul Hakim, S. Jaganath, M.K. Honnabyraiah, S. Mohan Kumar, S. Anil Kumar and Dayamani, K.J. 2018. Influence of Biofertilizer and Auxin on Growth and Rooting of Pomegranate (Punica granatum L.) Cuttings. Int.J.Curr.Microbiol.App.Sci. 7(02): 1187-1193. doi: https://doi.org/10.20546/ijcmas.2018.702.146 